\title{
PENGARUH TRUST IN A BRAND, BRAND AWARENESS TERHADAP BRAND LOYALTY KONSUMEN AIR MINERAL MEREK AQUA DI DENPASAR
}

\author{
Nofita Sari Ndoen ${ }^{1}$ \\ Ni Made Yudhaningsih ${ }^{2}$ \\ Program Studi Manajemen, Fakultas Ekonomi, Universitas Mahendradatta \\ J1. Ken Arok No 12, Peguyangan Denpasar Utara, Bali 80115 \\ 1Email : Nofitasarindoen015@gmail.com \\ 2 Email : Nimadeyuudhaningsih@gmail.com
}

\begin{abstract}
Abstrak - Penelitian ini di uji pada konsumen air mineral merk Aquqdi wilayah Denpasar. Aqua merupakan salah satu merek air mineral yang di wilayah Denpasar. Tujuan dari penelitian ini adalah untuk mengetahui signifikansi pengaruh trust in a brand, brand awareness terhadap brand loyalty konsumen air mineral merek Aqua secara parsial dan simultan terhadap brand loyalty konsumen air mineral merek Aqua di Denpasar. Dengan trust in a brand $\left(\mathrm{X}_{1}\right)$ dan brand awareness $\left(\mathrm{X}_{2}\right)$ sebagai variabel bebas dan brand loyalty konsumen (Y) sebagai variabel terikat. Penelitian ini menggunakan instrumen penelitian berupa kuesioner dengan sampel sebanyak 100 orang responden dengan teknik populasi dan sampel. Pengumpulan data juga dengan menggunakan metode observasi, studi kepustakaan dan wawancara. Teknik analisis dengan uji regresi linear berganda, uji-t, uji-F dan determinasi yang sebelumnya telah dilakukan uji validitas dan reliabilitas untuk menguji butir kuesioner serta telah dilakukan uji klasik untuk model regresi dengan program SPSSversi 20.0 .

Hasil penelitian menyatakan variabel bebas secara simultan berpengaruh positif dan signifikan terhadap variabel terikat yaitu terbukti dari uji-F diperoleh $\mathrm{F}$ hitung $=84,82>\mathrm{F}_{\text {-tabel }}=3,09$ dan 0,00 $<0,05$ dan besar pengaruh yang diberikan $62,90 \%$. Hasil uji-t diperoleh bahwa variabel trust in a brand $\left(\mathrm{X}_{1}\right)$ berpengaruh positif dan signifikan terhadap brand loyalty konsumen dengan koefisien regresi sebesar 0,003 satuan dan terbukti dengan hasil $t_{\text {hitung }} 3,100>t_{\text {tabel }} 1,984$ dan Sig. $t$ $0,003<0,05$. Pengaruh positif diberikan oleh variabel brand awareness $\left(\mathrm{X}_{2}\right)$ dan berpengaruh positif dan signifikan terhadap brand loyalty konsumen berdasarkan uji-t yaitu t-hitung $=6,980>\mathrm{t}$-tabel $=1,984$ dan Sig. $\mathrm{t}=0,003>0,05$ dan pengaruh yang diberikan dengan koefisien regresi hanya sebesar 0,801. Sehingga diperoleh persamaan regresinya $\mathrm{Y}=0,688+0,037 \mathrm{X}_{1}+0,801 \mathrm{X}_{2}$. Untuk itu pihak perusahaan/pimpinan perusahaan selayaknya memperhatikan variabel bebas secara bersama-sama karena pengaruh yang diberikan akan lebih besar.
\end{abstract}

Kata kunci : trust in a brand, brand awareness, brand loyalty 


\begin{abstract}
This study was tested on consumers of Aquq brand mineral water in the Denpasar area. Aqua is one of the mineral water brands in the Denpasar area. The purpose of this study was to determine the significance of the influence of trust in a brand, brand awareness on brand loyalty of Aqua brand mineral water consumers partially and simultaneously to brand loyalty of consumers of Aqua brand mineral water in Denpasar. With trust in a brand (X1) and brand awareness (X2) as independent variables and consumer brand loyalty $(Y)$ as the dependent variable. This study uses research instruments in the form of questionnaires with a sample of 100 respondents with population and sample techniques. Data collection also uses the method of observation, literature study and interview. Analysis technique with multiple linear regression test, $t$-test, $F$-test and determination of the validity and reliability of the previous test has been done to test the questionnaire items and classical tests have been done for the regression model with SPSSversion 20.0 program.

The results of the study stated that independent variables simultaneously have a positive and significant effect on the dependent variable which is evident from the $F$-test obtained by F-count $=84.82>F$-table $=3.09$ and $0.00<0.05$ and the magnitude of the influence given 62,90\%. T-test results obtained that the trust in a brand variable (X1) has a positive and significant effect on consumer brand loyalty with a regression coefficient of 0.003 units and is proven by the results of tcount 3,100>t table 1,984 and Sig. $t 0.003<0.05$. Positive influence is given by brand awareness variable (X2) and has a positive and significant effect on consumer brand loyalty based on $t$-test that is $t$-count $=6.980>t$-table $=1.984$ and Sig. $t=0.003>0.05$ and the effect given with the regression coefficient is only 0.801 . So that the regression equation is obtained $Y=0.688+0.037 X 1+0.801 X 2$. For that the company / company leadership should pay attention to the independent variables together because the influence given will be greater.
\end{abstract}

Keywords: trust in a brand, brand awareness, brand loyalty 
Jurnal Satyagraha, Vol. 01, No. 02, Agustus 2018 - Januari 2019 ISSN : 2620-6358

\section{PENDAHULUAN}

Meningkatnya permintaan dari masyarakat akan kebutuhan air bersih, maka banyak bermunculan perusahaan- perusahaan yang memproduksi Air Minum Dalam Kemasan dengan berbagai merek dan bentuk kemasan seperti: Vit, Lee mineral, Nestle, spring, Aqua, cleo, Ades, club dan berbagai jenis merek lainnya Hal tersebut mengakibatkan semakin ketatnya persaingan antara perusahaan air mineral. Seiring berkembangnya teknologi, perusahaan Air Mineral Dalam Kemasan saling berlomba untuk meningkatkan kualitas dan melakukan inovasi - inovasi produk air mineral yang bertujuan untuk menarik konsumen. Dalam persaingan produk kepercayaan merek (Brand Trust ) sangatlah penting dimana kepercayaan merek (Brand Trust ) adalah: kesediaan konsumen untuk mempercayai suatu merek dengan segala resikonya karena adanya harapan di benak mereka bahwa merek tersebut akan memberikan hasil yang positif kepada konsumen sehingga akan menimbulkan kesetiaan terhadap suatu merek.

Kesadaran Merek (brand awareness) adalah : kesanggupan seorang pembeli untuk mengenali atau mengingat kembali bahwa suatu merek merupakan bagian dari kategori produk tertentu.(Aaker dalam Rangkuti, 2002) Brand awareness juga merupakan hal yang penting dalam konsumen untuk menentukan keputusan pembelian. Loyalitas merek (brand loyalty) adalah : preferensi konsumen secara konsisten untuk melakukan pembelian pada merek yang sama pada produk yang spesifik atau kategori pelayanan tertentu ( Schiffman dan Kanuk 2004 :227) loyalitas merek juga merupakan cerminan loyalitas konsumen pada suatu merek tertentu yang tercipta karena beberapa faktor yang mempengaruhi. Loyalitas merek terjadi karena adanya kepuasan konsumen akan suatu produk, konsumen mempunyai komitmen terhadap merek tersebut dan konsumen akan memiliki kecenderungan untuk meneruskan pembelian akan merek tersebut secara berkelanjutan.

Berikut ini adalah data tingkat presentase Air Mineral Dalam Kemasan, yang di minati oleh konsumen Indonesia berdasarkan hasil dari Top Brand Index.

\section{Tabel 1.1}

Top Brand Index kategori air minum dalam kemasan

tahun 2012 - 2015

\begin{tabular}{|c|c|c|c|c|}
\hline $\begin{array}{c}\text { MER } \\
\text { EK }\end{array}$ & $\begin{array}{c}\text { TOP } \\
\text { BRA } \\
\text { ND } \\
\text { INDE } \\
\text { X } \\
2012 \\
\end{array}$ & $\begin{array}{c}\text { TOP } \\
\text { BRA } \\
\text { ND } \\
\text { INDE } \\
\quad \mathrm{X} \\
\mathbf{2 0 1 3} \\
\end{array}$ & $\begin{array}{c}\text { TOP } \\
\text { BRA } \\
\text { ND } \\
\text { INDE } \\
\quad \mathrm{X} \\
2014 \\
\end{array}$ & $\begin{array}{c}\text { TOP } \\
\text { BRA } \\
\text { ND } \\
\text { INDE } \\
X \\
2015 \\
\end{array}$ \\
\hline $\begin{array}{c}\text { AQU } \\
\text { A }\end{array}$ & $\begin{array}{c}81,0 \\
\%\end{array}$ & $\begin{array}{c}81,6 \\
\%\end{array}$ & $75,2 \%$ & $\begin{array}{c}75,90 \\
\%\end{array}$ \\
\hline Club & $3,2 \%$ & $3,7 \%$ & $3,4 \%$ & $\begin{array}{c}5,00 \\
\%\end{array}$ \\
\hline VIT & $2,1 \%$ & $3,1 \%$ & $3,2 \%$ & $\begin{array}{c}2,60 \\
\%\end{array}$ \\
\hline Ades & $2,6 \%$ & $2,3 \%$ & $2,2 \%$ & $\begin{array}{c}2,60 \\
\%\end{array}$ \\
\hline
\end{tabular}

Sumber ; http;//www.topbrand-award.com

Dari tabel diatas dapat kita peroleh informasi hasil dari Top Brand Index pada tahun 2012 merek Aqua berada pada posisi ( 81,0\%) ditahun 2013 Aqua naik pada posisi $(81,6 \%)$, pada tahun 2014 aqua hanya berada pada presentase $(75,2 \%)$ dan ditahun 2015 kembali naik dan berada pada posisi 
Jurnal Satyagraha, Vol. 01, No. 02, Agustus 2018 - Januari 2019 ISSN : 2620-6358

(75,90\%). Diikuti merek Club tahun 2012 berada pada posisi (3,2\%), tahun 2013 naik pada posisi $(3,7 \%)$ tahun 2014 Club turun pada posisi $(3,4 \%)$ dan kembali naik ditahun 2015 sebesar (5,00\%). Selanjutnya presentase merek Vit di tahun 2012 adalah $(2,1 \%) 2013$ Vit berhasil naik pada posisi $(3,1 \%)$ di tahun 2014 merek Vit menempati posisi $(3,2 \%)$, tahun 2015 kembali turun dan berada pada posisi $(2,60 \%)$. yang terakhir adalah merek Ades ditahun 2012 berada pada posisi $(2,6 \%)$ turun di tahun 2013 menjadi (2,3\%) tahun 2014 Ades berada pada posisi $(2,2 \%)$ dan di tahun terakhir 2015 Ades menempati posisi yang sama dengan merek Vit yaitu $(2,60 \%)$. pada tahun terakhir yaitu 2015 air mineral merek Aqua berada pada tingkat Top Brand Index tertinggi dengan presentase $75,90 \%$ di peringkat kedua air mineral merek Club memperoleh tingkat presentase sebanyak 5,00\% sedangkan pada peringkat ketiga air mineral merek VIT dan Ades memperoleh tingkat Top Brand Index dengan presentase $2,60 \%$.

Jika kita lihat dari keseluruhan tabel Top Brand Index dari Tahun 2012 sampai dengan tahun 2015, dapat kita lihat bahwa Air Mineral Dalam Kemasan, merek AQUA merupakan merek air mineral yang paling diminati oleh konsumen sehingga mendapatkan posisi teratas dalam Top Brand Index. Hal tersebut di duga menunjukkan adanya hubungan keterkaitan dengan Brand Trust, Brand Awareness, dan Brand Loyalty Pada konsumen air mineral merek Aqua.

\section{METODE PENELITIAN}

\section{Rancangan penelitian}

Menurut Teguh (2005 : 87) menyatakan bahwa rencana penelitian adalah spesifikasi metode - metode atau prosedur - prosedur guna menentukan informasi yang dibutuhkan untuk menyusun atau memecahkan masalah.

Penelitian ini dimulai dengan menentukan masalah yang akan diteliti untuk memperkecil cakupan permasalahan karena adanya keterbatasan masalah. Untuk mempermudah penelitian diperlukan metodologi penelitian yang berguna dalam pencarian data dan penentuan teknik analisis data. Pada penelitian ini peneliti meneliti mengenai pengaruh trust in a brand,brand awareness terhadap brand loyalty konsumen air mineral merek aqua di Denpasar.

\section{Operasional Variabel Penelitian}

\section{Variabael Bebas}

Variabel bebas adalah variabel yang menyebabkan atau memengaruhi, faktorfaktor yang diukur, dimanipulasi atau dipilih oleh peneliti untuk menentukan hubungan antara fenomena yang

diobservasi atau diamati. Dalam penelitian ini yang menjadi variabel bebas adalah brand trust dan brand awareness

\section{Brand Trust $\left(X_{1}\right)$}

Brand trust yang dimaksud dalam penelitian ini adalah bagaimana kemampuan aqua untuk dipercaya bersumber pada keyakinan konsumen bahwa aqua dapat memenuhi nilai yang dijanjikan aqua terhadap konsumen. Adapun indikator brand trust yang digunakan untuk menguji sejauh mana konsumen percaya bahwa aqua dapat memenuhi kebutuhannya. Indikator yang dipakai menurut (Delgado et al, 2005:191) sebagai berikut: 1) merek sesuai harapan yang diberikan aqua kepada konsumen seperti cita rasa, 2) percaya terhadap merek aqua 3) merek menjamin kepuasan disini aqua mampu memberikan kepuasan kepada 
Jurnal Satyagraha, Vol. 01, No. 02, Agustus 2018 - Januari 2019 ISSN : 2620-6358

pelanggan 4) merek dapat diandalkan,yang diberikan aqua kepada pelanggan seperti kemasan yang bervariasi jadi bisa di bawah kemana saja dan kapan pun 5) merek jujur apa adanya dalam meperhatikan kebutuhan, seperti volume atau isi yang sesuai dengan takaran 6) merek berusaha memuaskan konsumen dalam mengatasi masalah, seperti yang diberikan aqua yaitu asupan mineral yang sesuai untuk mengatasi kekurangan ion dalam tubuh.

\section{Brand awareness $\left(\mathrm{X}_{2}\right)$}

Dalam penelitian ini yang dimaksud adalah bagaimana konsumen dapat mengenali merek aqua dalam situasi yang berbeda. Indikator yang digunakan untuk menguji tingkat kesadaran merek didasarkan (Kotler dan Keler 2009: 269) sebagai berikut: 1) posisi merek dalam ingatan,dimana timbal balik konsumen terhadap merek aqua sehingga membuat aqua berada dalam posisi pertama dalam bebrbagai macam merek lain2) kemampuan mengingat varian,konsumen mampu mengingat varian seperti yang diberikan merek aqua mealui logo, desain, simbol dari merek aqua tersebut 3) kemampuan mengingat slogan, aqua memberikan slogan yang mudah dingat sehingga kapan saja dan dimana saja konsumen mendengar, membaca atau menontonnya di televisi konsumen dapat mengenali bahwa ini adalah slogan merek aqua.

\section{Variabel Terikat (Y)}

Variabel terikat adalah faktor- faktor yang diobservasi dan diukur untuk menetukan adanya pengaruh variabel bebas, yaitu faktor yang muncul, atau tidak muncul, atau berubah sesuai dengan yang diperkenalkan oleh peneliti dalam penelitian ini yang menjadi variabel terikat yaitu Brand Loyalty.

\section{Brand loyalty ( $Y$ )}

yang dimaksud dalam brand loyalty ini adalah ukuran tingkat pembelian kembali pada merek aqua. Indikator yang digunakan menurut (Delgado et al, 2005: 191) yaitu :1) konsumen setia kepada merek dalam hal ini merek aqua 2) hanya dalam terpaksa konsumen mempertimbangkan untuk membeli merek yang berbeda, jika tidak tersedia merek aqua 3) mencari toko lainnya untuk merek tersebut bila tidak tersedia ditoko tersebut seperti konsumen hanya ingin berpegang pada merek aqua saja 4) dan konsumen merekomendasikan merek dalam hal ini konsumen dengan sendirinya akan merekomendasi hal positif kepada kerabat, atau orang lain.

\section{Populasi}

Populasi merupakan keseluruhan unsurunsur dari subjek penelitian yang memiliki satu atau beberapa karaktristik yang sama. Adapun populasi dalam penelitian ini semua orang yang mengomsumsi air mineral merek AQUA di denpasar

\section{Sampel}

Sampel adalah bagian dari populasi yang diambil melalui cara- cara tertentu yang juga memiliki karakteristik tertentu, jelas dan lengkap yang di anggap bisa mewakili populasi. Sampel yang digunakan yaitu belum bisa diketahui. Teknik pengambilan sampel dalam penelitian ini menggunakan teknik purposive sampling. Jadi sampel tidak diambil secara acak tapi ditentukan sendiri oleh peneliti berdasarkan pertimbangan tertentu.

\section{METODE PENGUMPULAN DATA}

Kuesioner (Angket)

Data dikumpulkan menggunakan metode survei melalui daftar pertayaan (kuesioner) kepada konsumen yang mengkomsumsi air 
Jurnal Satyagraha, Vol. 01, No. 02, Agustus 2018 - Januari 2019 ISSN : 2620-6358

mineral merek aqua yang berada di kota Denpasar. Metode Survei bertujuan untuk meliput banyak orang sehingga hasil survei dapat dipandang mewakili populasi atau merupakan generalisasi (Istijanto, 2005). Bentuk survei yang dijalankan adalah survei secara individu, dimana survei dijalankan oleh peneliti dengan mememui responden secara bertatap muka.

\section{Teknik Analisis Data}

Penyelesaian penelitian ini dengan mengunakan teknik analisis kuantitatif. Dalam penelitian ini, karena jenis data yang digunakan adalah data kuantitatif, maka analisis kuantitatif dilakukan dengan cara mengkuantifikasi data- data penelitian kedalam bentuk angka -angka dengan menggunakan skala rasio (ratio scale) dan skala likert 5 poin (5- point likert scale). Alat analisis yang digunakan dalam penelitian ini analisis regresi linear berganda dengan program SPSS 20. Teknik pengumpulan sampel pada umumnya dilakukan secara random, pengumpulan data menggunakan instrumen penelitian, analisis data bersifat kuantitatif atau statistik dengan tujuan untuk menguji hipotesis yang telah ditetapkan (Sugiyono, 2012).

Untuk menentukan data kuantitatif, digunakan skala likert yaitu skala yang berisi lima tingkat preferensi jawaban dengan pilihan sebagai berikut:

$1=$ Sangat tidak setuju, $2=$ Tidak setuju, $3=$ Netral, $4=$ Setuju, $5=$ Sangat setuju

Nilai skor frekuensi, $\mathrm{STS}=1, \mathrm{TS}=2, \mathrm{~N}=3$, $\mathrm{S}=4, \mathrm{SS}=5$

Analisis yang digunakan adalah regresi linear berganda, sebelum itu dilakukan uji kualitas data terlebih dahulu.

HASIL PENELITIAN DAN UJI HIPOTESIS Karakteristik Responden
Data yang dianalisis dalam penelitian ini berdasar pada hasil pengumpulan dari distribusi kuesioner ke seluruh responden sebanyak 100 responden. Kuesioner yang telah terkumpul, selanjutnya diperiksa untuk memastikan kelengkapan kuesioner yang telah diisi responden. Hasil pemeriksaan menunjukkan seluruh kuesioner dapat diikutsertakan dalam analisis, karena pengisiannya telah lengkap. Analisis data yang dilakukan dalam penelitian ini antara lain adalah analisis statistik deskriptif dan inferensial. Untuk analisis deskriptif, tahap awal dilakukan analisis terhadap karakteristik responden yang disajikan dalam Tabel 1.2.

Tabel 1.2.

Demografi Responden

\begin{tabular}{|l|l|c|c|}
\hline $\begin{array}{c}\text { N } \\
\text { o. }\end{array}$ & Karakteristik & $\begin{array}{c}\text { Jumla } \\
\mathbf{h} \\
(\text { Oran } \\
\text { g) }\end{array}$ & $\begin{array}{c}\text { Present } \\
\text { ase }(\%)\end{array}$ \\
\hline 1 & Jenis Kelamin : & & \\
& $\bullet$ Laki-Laki & 48 & 48.0 \\
& $\bullet$ Perempuan & 52 & 52.0 \\
\hline & Total & 100 & 100 \\
\hline 2 & Tingkat Usia : & 16 & 16.0 \\
& $\bullet<20$ tahun & 24 & 24.0 \\
& $\bullet 20-25$ tahun & 24 & 24.0 \\
& $\bullet 26-30 t a h u n$ & 20 & 20.0 \\
& $\bullet 31-35$ tahun & 16 & 16.0 \\
\hline & $\bullet>35$ Tahun & 100 & 100 \\
\hline 3 & Total & 11 & 11.0 \\
\hline
\end{tabular}


Jurnal Satyagraha, Vol. 01, No. 02, Agustus 2018 - Januari 2019 ISSN : 2620-6358

\begin{tabular}{|l|l|c|c|}
\hline $\begin{array}{c}\text { N } \\
\text { o. }\end{array}$ & Karakteristik & $\begin{array}{c}\text { Jumla } \\
\text { h } \\
\text { (Oran } \\
\text { g) }\end{array}$ & $\begin{array}{c}\text { Present } \\
\text { ase (\%) }\end{array}$ \\
\hline & $\bullet$ Pelajar/mahasi & 43 & 43.0 \\
& swa & 25 & 25.0 \\
& $\bullet$ Wiraswasta & 12 & 12.0 \\
& $\bullet$ PNS/BUMN & 9 & 9.0 \\
& $\bullet$ Pegawai/Swas & & \\
& ta & & \\
& $\bullet$ Lainnya & & \\
\hline & Total & 100 & 100 \\
\hline
\end{tabular}

Sumber : Hasil Analisa

Paparan Tabel 1.1 di atas dapat dijelaskan bahwa demografi responden berdasarkan jenis kelamin, tampak kaum perempuan memiliki distribusi lebih banyak sebesar 52.0 persen sedangkan kaum laki-laki yang memiliki distribusi sebesar 48.0 persen. Untuk demografi responden berdasarkan tingkat usia menunjukkan, responden yang berusia 20-25 tahun dan 26-30 lebih banyak dengan distribusi sebesar masing-masing 24.0 persen. Selanjutnya, diikuti usia responden 31-35 tahun sebesar 20 persen dan usia responden $<20$ tahun dan $>35$ tahun masing-masing sebesar 16.0 persen. Pada demografi berdasarkan pekerjaan, tampak reponden sebagai wiraswasta memiliki kontribusi tertinggi yaitu sebesar 43.0 persen, kemudian PNS/BUMN sebesar 25.0 persen, pegawai/swasta sebesar 12.0 persen, pelajar/mahasiswa sebesar 11.0 persen dan terakhir diluar dari profesi tersebut sebesar 9.0 persen.

\section{Uji Validitas dan Reliabilitas}

Yang diuji validitas dan reliabilitas adalah masing- masing kuesioner yang memuat 13 peryataan. Dari 13 item peryataan tersebut, 9 item peryataan digunakan untuk mengukur variabel bebas yaitu 6 item untuk brand trust $\left(\mathrm{X}_{1}\right), 3$ item pertanyaan untuk brand awareness $\left(\mathrm{X}_{2}\right)$ dan4 item pernyataan digunakan untuk mengukur variabel terikat brand loyalty $(\mathrm{Y})$ konsumen air mineral merek Aqua di Denpasar.

\section{Uji Validitas}

Uji validitas bertujuan untuk mengetahui apakah instrumen mampu tidak mengukur apa yang seharusnya diukur. Untuk mengetahui valid tidaknya item pernyataan dilakukan dengan membandingkan koefisien korelasi Product Moment Person yang diperoleh dari hasil pengolahan data dengan menggunakan program SPSS for Windows versi 20.0 (r-hitung) dengan nilai kritis korelasi pada tabel Product Moment (r-tabel) pada tingkat kepercayaan $95 \%$ dan tingkat kesalahan atau taraf signifikan (alpha 5\%), sehinga didapat r-tabel yaitu sebesar 0,3. Item Pernyataan dinyatakan valid apabila memiliki r-hitung > r-tabel atau memiliki nilai signifikan < alpha 5\% $(0,05)$. Adapun hasil uji validitas butir-butir pernyataan variabel bebas brand trust $\left(\mathrm{X}_{1}\right)$, brand awareness $\left(\mathrm{X}_{2}\right)$ serta variabel terikat brand loyalty (Y) pada Konsumen air mineral merek Aqua di Denpasar dapat disajikan pada tabel berikut.

Tabel 1.3.

\section{Hasil Uji Validitas Variabel} Penelitian 
Jurnal Satyagraha, Vol. 01, No. 02, Agustus 2018 - Januari 2019 ISSN : 2620-6358

\begin{tabular}{|c|c|c|c|}
\hline $\begin{array}{c}\text { Item } \\
\text { Pertanyaan }\end{array}$ & $\begin{array}{c}\text { r- } \\
\text { hitun } \\
\text { g }\end{array}$ & $\begin{array}{c}\text { r- } \\
\text { tabe } \\
1\end{array}$ & $\begin{array}{c}\text { Keteranga } \\
\text { n }\end{array}$ \\
\hline $\begin{array}{l}\text { Brand trust } \\
\left(\mathrm{X}_{1}\right)\end{array}$ & & & \\
\hline X1.1 & 0,870 & 0,30 & Valid \\
\hline X1.2 & 0,509 & 0,30 & Valid \\
\hline X1.3 & 0,830 & 0,30 & Valid \\
\hline X1.4 & 0,855 & 0,30 & Valid \\
\hline X1.5 & 0,722 & 0,30 & Valid \\
\hline X1.6 & 0,891 & 0,30 & Valid \\
\hline $\begin{array}{l}\text { Brand } \\
\text { awareness (X } \\
\text { 2) }\end{array}$ & & & \\
\hline $\mathrm{X} 2.1$ & 0,546 & 0,30 & Valid \\
\hline $\mathrm{X} 2.2$ & 0,703 & 0,30 & Valid \\
\hline X2.3 & 0,726 & 0,30 & Valid \\
\hline $\begin{array}{l}\text { Brand } \\
\text { loyalty }(\mathrm{Y})\end{array}$ & & & \\
\hline Y.1 & 0,687 & 0,30 & Valid \\
\hline
\end{tabular}

\begin{tabular}{|l|c|c|c|}
\hline \multicolumn{1}{|c|}{ Item } & r- & r- & Keteranga \\
Pertanyaan & hitun & tabe & n \\
& $\mathbf{g}$ & $\mathbf{l}$ & \\
\hline \hline Y.2 & 0,700 & 0,30 & Valid \\
\hline Y.3 & 0,741 & 0,30 & Valid \\
\hline Y.4 & 0,689 & 0,30 & Valid \\
\hline
\end{tabular}

\section{Sumber : Hasil Analisa}

[1] Dari tabel 1.3. di atas dapat disimpulkan bahwa item-item pernyataan baik yang digunakan untuk mengukur variabel bebas brand trust $\left(\mathrm{X}_{1}\right)$, brand awareness $\left(\mathrm{X}_{2}\right)$ maupun yang digunakan untuk mengukur variabel terikat brand loyalty (Y) dinyatakan valid karena masingmasing item pertanyaan tersebut memiliki koefisien r-hitung yang lebih besar dari koefisien r-tabel.

\section{Uji Reliabilitas}

Reliabilitas bertujuan untuk mengetahui apakah alat ukur atau instrumen penelitian dapat memberikan hasil yang konsisten atau tidak apabila instrumen tersebut digunakan lagi untuk mengukur objek yang sama pada waktu yang berbeda. Pengujian reliabilitas instrumen dilakukan dengan menggunakan koefisien Cronbach's Alpha. Sebagai pedoman umum untuk menentukan reliabilitas item pernyataan maka koefisien korelasi minimum dianggap memenuhi syarat atau reliabel adalah jika Cronbach's Alpha atau $\mathrm{r} \geq 0,600$ dan apabila $\mathrm{r}$ lebih kecil dari 0,600 maka butir pertanyaan dinyatakan tidak reliable, (Simamora, 2004:175). 
Jurnal Satyagraha, Vol. 01, No. 02, Agustus 2018 - Januari 2019 ISSN : 2620-6358

Adapun hasil uji reliabilitas dapat disajikan sebagai berikut.

Tabel 1.4.

Hasil Uji Reliabilitas Variabel

Penelitian

\begin{tabular}{|c|l|l|l|}
\hline $\mathbf{N}$ & Variabel & $\begin{array}{c}\text { Koefisie } \\
\mathbf{n} \\
\text { Cronbac } \\
\boldsymbol{h} \text { 's } \\
\text { Alpha }\end{array}$ & $\begin{array}{c}\text { Keterang } \\
\text { an }\end{array}$ \\
\hline 1 & $\begin{array}{c}\text { Brand } \\
\text { trust }\left(\mathrm{X}_{1}\right)\end{array}$ & 0,921 & Reliabel \\
\hline 2 & $\begin{array}{c}\text { Brand } \\
\text { awareness }( \\
\left.\mathrm{X}_{2}\right)\end{array}$ & 0,807 & Reliabel \\
\hline 3 & $\begin{array}{l}\text { Brand } \\
\text { loyalty(Y) }\end{array}$ & 0,857 & Reliabel \\
\hline
\end{tabular}

Sumber :Hasil analisa

[2] Berdasarkan tabel 1.4. di atas terlihat bahwa kedua variabel penelitian, yaitu variabel bebas brand trust $\left(\mathrm{X}_{1}\right)$ dan brand awareness $\left(\mathrm{X}_{2}\right)$ serta variabel terikat brand loyalty (Y) yang di uji reliabilitasnya dinyatakan reliabel karena memiliki Cronbach's Alpha yang lebih besar dari 0,600 .

ANALISIS KUANTITATIF Analisis Regresi Linier Berganda

Berikut ini akan diuraikan pengaruh variabel brand trust $\left(\mathrm{X}_{1}\right)$ dan brand awareness $\left(\mathrm{X}_{2}\right)$ terhadap variabel brand loyalty (Y) konsumen air mineral merek Aqua di Denpasar. Analisis berikut ini didasarkan pada perhitungan dengan menggunakan bantuan program SPSS versi 20,0. Dari hasil analisis data, nilai konstanta dan koefisien regresi dari variabel-variabel penelitian tampak seperti tabel 1.5 . berikut ini :

\section{Tabel 1.5.}

Nilai Konstanta dan Koefisien Regresi Variabel-Variabel Penelitian

Coefficients $^{\mathbf{a}}$

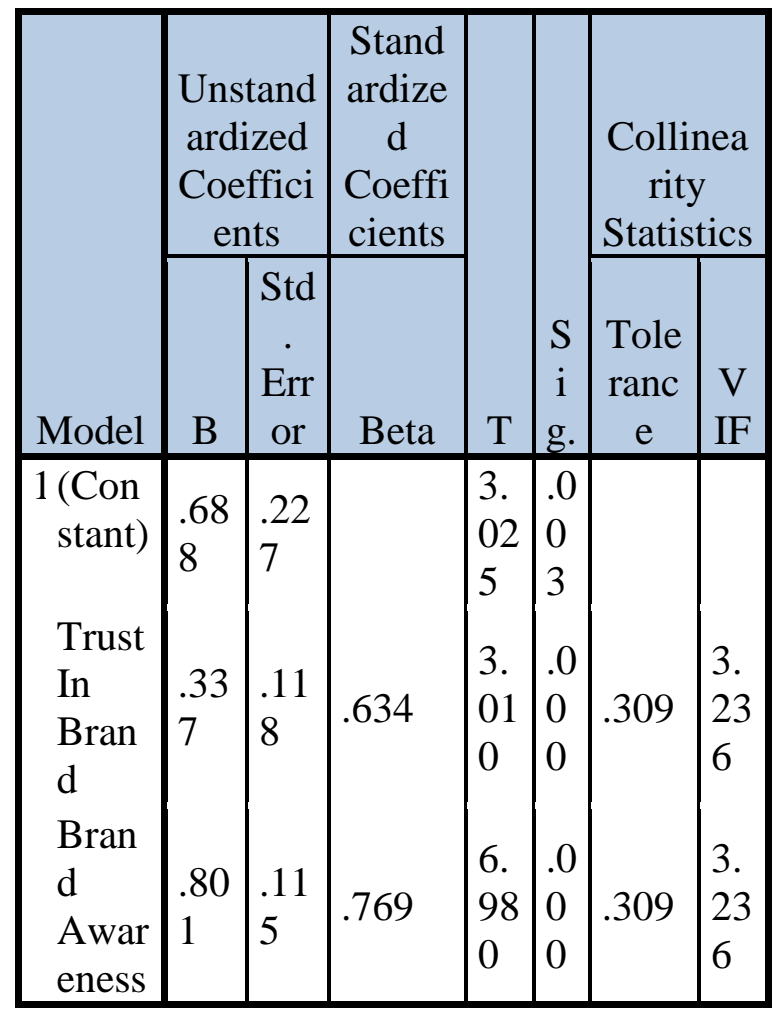

a. Dependent Variable: Brand Loyality

\section{Sumber : Hasil analisa}

Berdasarkan tabel diatas diperoleh nilai konstanta (a) dan koefisien regresi $(\beta)$, sebagai berikut :

$$
\begin{aligned}
& a=0,688 \\
& \beta_{1}=0,337 \\
& \beta_{2}=0,801
\end{aligned}
$$

Dengan diketahui $\mathrm{a}=0,688, \beta_{1}=0,337, \beta_{2}=$ 0,801 maka dapat dibuat persamaan regresi berganda sebagai berikut :

$$
\begin{aligned}
& Y=a+\beta_{1} X_{1}+\beta_{2} X_{2} \\
& Y=0,688+0,337 X_{1}+0,801 X_{2}
\end{aligned}
$$

Dari model regresi tersebut, dapat dijelaskan hubungan kausal atau pola pengaruh variabel bebas yang meliputi brand trust (X1) dan brand awareness (X2) seara 
Jurnal Satyagraha, Vol. 01, No. 02, Agustus 2018 - Januari 2019 ISSN : 2620-6358

simultan (bersama-sama) terhadap variabel terikat brand loyalty (Y) pada konsumen air mineral merek Aqua di Denpasar sebagai berikut.

a) Nilai koefisien brand trust sebesar 0,337, artinya bahwa setiap kenaikan brand trust, maka variabel brand loyalty akan meningkat sebesar 0,337 dengan asumsi bahwa variabel brand awareness adalah tetap.

b) Nilai koefisien brand awareness sebesar 0,801 , artinya bahwa setiap kenaikan brand awareness, maka variabel brand loyalty akan meningkat sebesar 0,801 dengan asumsi bahwa variabel brand trust adalah tetap.

Dari uraian diatas dapat disimpulkan bahwa secara simultan variabel bebas brand trust dan brand awareness memiliki pola pengaruh yang positif terhadap variabel terikat brand loyalty konsumen air mineral merek Aqua di Denpasar karena masingmasing koefisien regresi variabel bebas menunjukkan angka positif.

\section{Analisis korelasi berganda}

Analisis korelasi berganda digunakan untuk mengetahui kuat lemahnya hubungan secara simultan antara brand trust $\left(\mathrm{X}_{1}\right)$ dan brand awareness $\left(\mathrm{X}_{2}\right)$ dengan brand loyalty (Y) konsumen air mineral merek Aqua di Denpasar. Dari hasil analisis data dengan bantuan program SPSS for windows versi 20.0, didapat angka korelasi seperti disajikan pada tabel berikut.

Tabel 1.6.

Hasil Uji Analisis Korelasi Model Summary ${ }^{b}$

\begin{tabular}{|l|l|l|l|l|l|}
\hline $\mathrm{R}$ & & & & Change Statistics \\
\hline
\end{tabular}

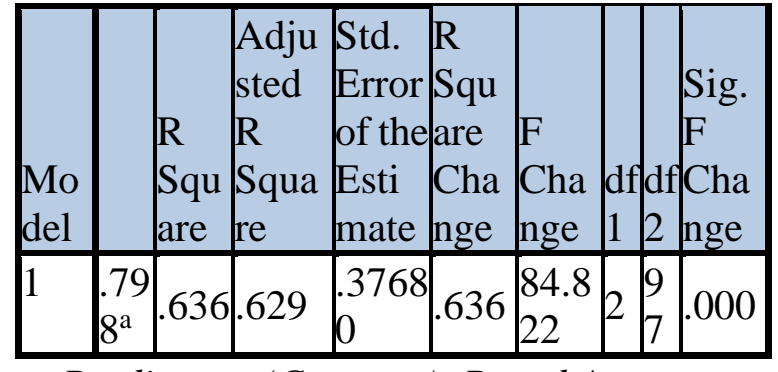

a. Predictors: (Constant), Brand Awareness, Trust In Brand

b. Dependent Variable: Brand Loyality

\section{Sumber: Data diolah}

Dari tabel 1.6. diatas diketahui angka korelasi antara variabel brand trust $\left(\mathrm{X}_{1}\right)$ dan brand awareness $\left(\mathrm{X}_{2}\right)$ dengan variabel brand loyalty (Y) yaitu sebesar 0,798. Angka korelasi tersebut jika dibandingkan dengan kriteria pengujian korelasi yang telah dikemukakan sebelumnya, maka terletak pada kisaran antara $0,71-0,90$ berarti korelasi kuat

Hal ini berarti bahwa hubungan secara simultan brand trust $\left(\mathrm{X}_{1}\right)$ dan brand awareness $\left(\mathrm{X}_{2}\right)$ dengan brand loyalty $(\mathrm{Y})$ konsumen air mineral merek Aqua di Denpasar berada pada korelasi kuat.

\section{Analisis Determinasi}

Analisis determinasi bertujuan untuk mengetahui sejauh mana pengaruh variabel bebas yang meliputi brand trust $\left(\mathrm{X}_{1}\right)$ dan brand awareness $\left(\mathrm{X}_{2}\right)$ terhadap variabel terikat brand loyalty (Y) konsumen air mineral merek Aqua di Denpasar yang dinyatakan dalam bentuk persentase. Determinasi dihitung dengan mengkuadratkan koefisien korelasi dan dikali dengan $100 \%$ atau dapat dilakukan dengan melihat nilai $R$ Square pada tabel Model Summary dari hasil analisis dengan bantuan program SPSS for Windows versi 20.0 dan dikalikan dengan $100 \%$. Adapun nilai $R$ 
Jurnal Satyagraha, Vol. 01, No. 02, Agustus 2018 - Januari 2019 ISSN : 2620-6358

Square dari hasil analisis SPSS versi 20.0 dapat disajikan pada tabel berikut.

Tabel 1.7.

Hasil Analisis Determinasi

Model Summary ${ }^{b}$

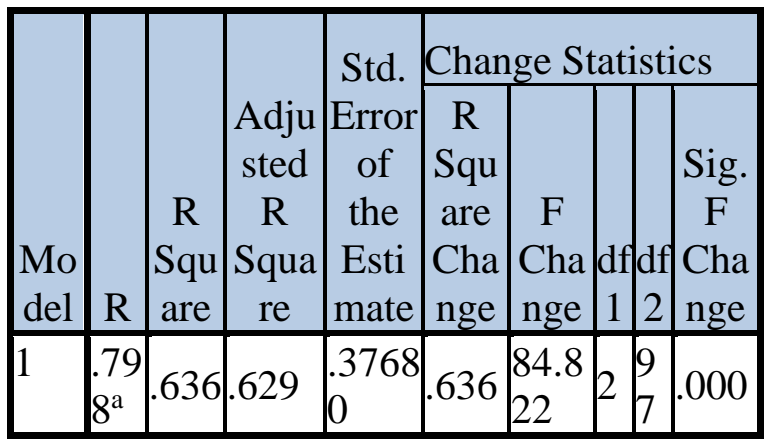

a. Predictors: (Constant), Brand Awareness, Trust In Brand

b. Dependent Variable: Brand Loyality

\section{Sumber: Hasil analisa}

Berdasarkan tabel 1.7. diatas dapat dihitung besarnya determinasi, yaitu sebagai berikut:

$$
\begin{aligned}
& D=R^{2} \times 100 \% \\
& D=0,636 \times 100 \% \\
& D=63,60 \%
\end{aligned}
$$

Koefisien determinasi sebesar 0,636 tersebut menunjukkan bahwa variabel bebas yang meliputi brand trust (X1) dan brand awareness (X2) dapat mempengaruhi variabel terikat brand loyalty (Y) sebesar $63,60 \%$, sedangkan sisanya $100 \%-63,60 \%=$ $36,40 \%$ dipengaruhi oleh faktor-faktor lain yang tidak diteliti.

\section{Uji t (T-test)}

Uji $t$ (t-test) ini digunakan untuk mengetahui atau membuktikan apakah terdapat pengaruh yang signifikan secara parsial antara variabel bebas yaitu brand trust $\left(\mathrm{X}_{1}\right)$ dan brand awareness $\left(\mathrm{X}_{2}\right)$ terhadap variabel terikat yaitu brand loyalty (Y) konsumen air mineral merek Aqua di Denpasar. Adapun uji t (t-test) dari masingmasing variabel bebas adalah sebagai berikut.

a. Uji t (t-test) atau uji parsial variabel brand trust $\left(\mathrm{X}_{1}\right)$ terhadap brand loyalty (Y).

\section{1) Pengujian Hipotesis}

Ho : $\beta_{1}=0$ berarti variabel bebas brand trust $\left(\mathrm{X}_{1}\right)$ secara parsial tidak berpengaruh signifikan terhadap variabel terikat, yaitu brand loyalty (Y).

Ha $: \beta_{1} \neq 0$ berarti variabel bebas brand trust $\left(\mathrm{X}_{1}\right)$ secara parsial berpengaruh signifikan terhadap variabel terikat, yaitu brand loyalty (Y).

2) Kriteria Pengujian Untuk menentukan $\mathrm{Ha}$ diterima atau Ho ditolak maka digunakan kriteria pengujian hipotesis sebagai berikut :

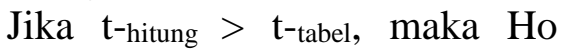
ditolak.

Jika t-hitung $\leq \mathrm{t}$-tabel, maka $\mathrm{Ha}$ ditolak.

3) Ketentuan pengujian menggunakan taraf kepercayaan 95\% dan taraf kesalahan 5\% (alpha 5\%) dengan df (degree of freedom $=$ derajat kebebasan) $\mathrm{n}$ $\mathrm{k}$, yaitu df $=100-3=97$. Jadi pada taraf kesalahan ( $\alpha$ 5\%), dengan $\mathrm{df}=97$, maka didapat besarnya $t_{\text {-tabel }}=1,661$.

Sedangkan besarnya nilai $t_{\text {hitung }}$ untuk variabel brand trust $\left(\mathrm{X}_{1}\right)$ didapat berdasarkan 
Jurnal Satyagraha, Vol. 01, No. 02, Agustus 2018 - Januari 2019 ISSN : 2620-6358

hasil perhitungan dengan menggunakan program SPSS versi 20.0 yaitu sebesar 3.010. Untuk lebih memperjelas hubungan parsial antara variabel bebas brand trust $\left(\mathrm{X}_{1}\right)$ dengan variabel terikat brand loyalty (Y), maka berikut akan digambarkan daerah penerimaan Ha dan penolakan Ho.

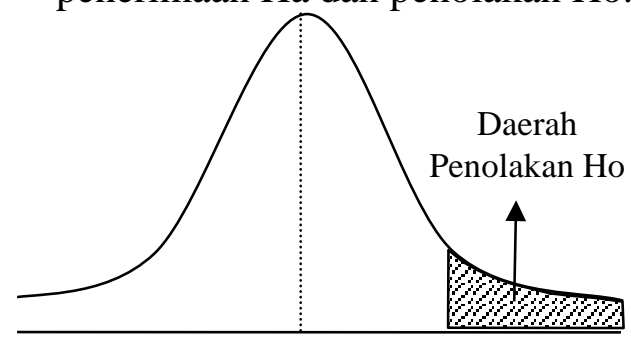

Gambar 1.P.Kritel ${ }^{t_{\text {tabel }}}$ 'ene $\mathrm{t}_{\text {hitun }}$ aan atau Penolakan Hipot 1,66 sec: ... parsial (Brand Trust Terhadap Brand Loyalty)

Gambar 1.1 di atas tampak jelas bahwa nilai $t_{\text {hitung }}=3,010$ jika dibandingkan dengan nilait $_{\text {tabel }}=1,661$, akan menunjukkan bahwa nilai $t_{\text {hitung }}$ lebih besar dari nilai $t_{\text {tabel }}$ dan nilai thitung berada pada daerah penolakan Ho. Dengan demikian Ho ditolak dan $\mathrm{Ha}$ diterima. Dalam hal ini brand trust sangat berpengaruh terhadap brand loyalty konsumen air mineral merek aqua di Denpasar.

b. Uji t (t-test) atau parsial variabel brand awareness $\left(\mathrm{X}_{2}\right)$ terhadap brand loyalty (Y).

1) Pengujian Hipotesis

Ho $: \beta_{2}=0$ berarti variabel bebas brand awareness $\left(\mathrm{X}_{2}\right)$ secara parsial tidak berpengaruh signifikan terhadap variabel terikat, yaitu brand loyalty (Y).

$\mathrm{Ha} \quad: \beta_{2} \neq 0$ berarti variab.. bebas brand awareness $\left(\mathrm{X}_{2}\right) \quad$ secara parsial berpengaruh signifikan terhadap variabel terikat, yaitu brand loyalty $(\mathrm{Y})$.

2) Kriteria Pengujian

Untuk menentukan Ha diterima atau Ho ditolak maka digunakan kriteria pengujian hipotesis sebagai berikut :

Jika t-hitung $>$ t-tabel, maka Ho ditolak.

Jika t-hitung $\leq \mathrm{t}_{\text {-tabel, }}$ maka $\mathrm{Ha}$ ditolak.

3) Ketentuan pengujian menggunakan taraf kepercayaan 95\% dan taraf kesalahan 5\% (alpha 5\%) dengan df (degree of freedom = derajat kebebasan) $n$ $\mathrm{k}$, yaitu df $=100-3=97$. Jadi pada taraf kesalahan ( $\alpha$ 5\%), dengan $\mathrm{df}=97$, maka didapat besarnya $t_{\text {-tabel }}=1,661$.

Sedangkan besarnya nilai $t_{h i t u n g}$ untuk variabel brand awareness $\left(\mathrm{X}_{2}\right)$ didapat berdasarkan hasil perhitungan dengan menggunakan program SPSS versi 20.0 yaitu sebesar 6.980. Untuk lebih memperjelas hubungan parsial antara variabel bebas brand awareness $\left(\mathrm{X}_{2}\right)$ dengan variabel terikat brand loyalty (Y), maka berikut akan digambarkan daerah penerimaan $\mathrm{Ha}$ dan penolakan Ho.

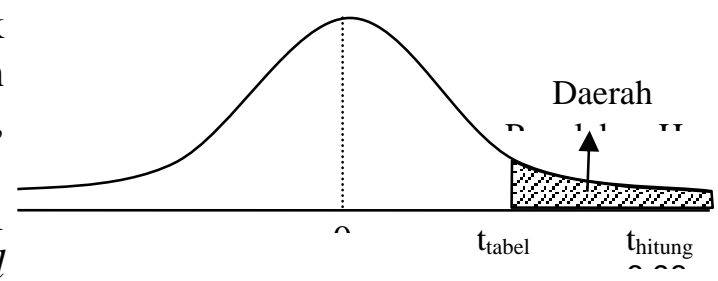

Gambar 1.2 Kriteria Penerimaan atau Penolakan Hipotesis secara 
Jurnal Satyagraha, Vol. 01, No. 02, Agustus 2018 - Januari 2019 ISSN : 2620-6358

\section{parsial (Brand Awareness}

Terhadap Brand Loyalty)

Gambar 1.2 di atas tampak jelas bahwa nilai $t_{\text {hitung }}=6.980$ jika dibandingkan dengan nilai $t_{\text {tabel }}=1,661$, akan menunjukkan bahwa nilai $t_{\text {hitung }}$ lebih besar dari nilai $t_{\text {tabel }}$ dan nilai

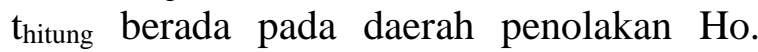
Dengan demikian Ho ditolak dan $\mathrm{Ha}$ diterima. Dalam artian bahwa brand awareness terbukti sangat berpengaruh terhadap brand loyalty konsumen air mineral merek aqua di Denpasar.

\section{Uji Secara Simultan (F-test)}

Untuk menguji nyata tidaknya pengaruh variabel-variabel bebas yaitu brand trust $\left(\mathrm{X}_{1}\right)$ dan brand awareness $\left(\mathrm{X}_{2}\right)$ secara simultan atau secara bersama-sama terhadap brand loyalty (Y), maka dilakukan pengujian dengan menggunakan uji F-test yang langkah-langkah pengujiannya adalah sebagai berikut :berikut :

a. Pengujian Hipotesis

Hipotesis yang diajukan dalam pengujian ini adalah "diduga brand trust $\left(\mathrm{X}_{1}\right)$ dan brand awareness $\left(\mathrm{X}_{2}\right)$ secara simultan berpengaruh signifikan terhadap brand loyalty (Y) konsumen air mineral merek Aqua di Denpasar". Berdasarkan hal tersebut, maka hipotesis dapat dirumuskan sebagai berikut :

Ho : $\beta_{1}, \beta_{2}=0$, berarti variabel bebas yang meliputi brand trust $\left(\mathrm{X}_{1}\right)$ dan brand awareness $\left(\mathrm{X}_{2}\right)$ secara simultan tidak berpengaruh signifikan terhadap variabel terikat yaitu brand loyalty (Y).
Ha : $\beta_{1}, \beta_{2} \neq 0$, berarti variabel bebas yang meliputi brand trust $\left(\mathrm{X}_{1}\right)$ dan brand awareness $\left(\mathrm{X}_{2}\right)$ secara simultan berpengaruh signifikan terhadap variabel terikat yaitu brand loyalty (Y).

b. Penentuan Statistik Tabel

Dalam pengujian ini digunakan F-tabel = $F_{(\alpha ; d f n, d f d)}$. Dengan taraf kepercayaan $(95 \%)$ dan taraf kesalahan (alpha 5\%)dengan dfn (degrees of freedom numerator/derajat bebas pembilang) $=\mathrm{k}-1=2$, dan dfd (degrees of freedom denominator/derajat bebas penyebut $)=n-k$. Jadi $n-k=100-3=97$. Jadi pada taraf $5 \%$, dengan dfn $=2$ dan $\mathrm{dfd}=97$, maka besarnya $\mathrm{F}_{(\alpha ; \mathrm{dfn} / \mathrm{dfd})}$ untuk $\mathrm{F}_{(5 \% ; 2 / 29)}$ adalah $=3,090$.

Sedangkan untuk $F_{\text {hitung,dari hasil }}$ perhitungan SPSS for Windows versi 20.0 ternyata pada dfn (degres of freedom numerator $=$ derajat bebas pembilang $)=2$ dan $\mathrm{dfd}$ (degres of freedom denominator $=$ derajat bebas penyebut) $=97$, diperoleh besarnya $F_{\text {hitung }}=84,822$.

c. Kriteria Penerimaan/Penolakan Hipotesis

Adapun kriteria penerimaan/penolakan hipotesis di atas adalah :

- Apabila F hitung > F tabel, maka Ho ditolak

- Apabila F hitung $\leq$ F tabel, maka Ha ditolak

Untuk lebih memperjelas hubungan simultan antara variabel bebas brand trust $\left(\mathrm{X}_{1}\right)$ dan brand awareness $\left(\mathrm{X}_{2}\right)$ terhadap variabel terikat yaitu brand loyalty $(\mathrm{Y})$, maka berikut akan digambarkan daerah penerimaan Ha dan penolakan Ho. 
Jurnal Satyagraha, Vol. 01, No. 02, Agustus 2018 - Januari 2019 ISSN : 2620-6358

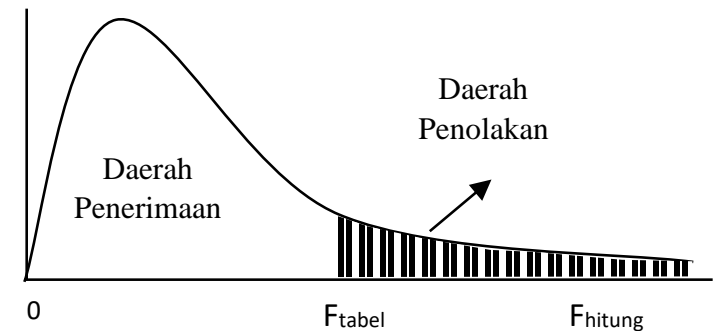

\section{Gambar 1.3. Kriteria Penerimaan atau} Penolakan

Gambar 1.3. di atas terlihat nilai $F_{\text {hitung }}=$ 84,822 jika dibandingkan dengan nilai $F_{\text {tabel }}=$ 3,090, maka nilai $F_{\text {hitung }}$ lebih besar dari nilai $F_{\text {tabel, dan nilai }} F_{\text {hitung }}$ berada pada daerah penolakan Ho. Oleh karena itu, Ho ditolak dan $\mathrm{Ha}$ diterima. Hal ini juga dibuktikan deengan hasil uji hipotesis dengan menggunakan SPSS for windows versi 20.0 dngan hasil sebagai berikut :

Untuk lebih memperjelas hubungan simultan antara variabel bebas brand trust $\left(\mathrm{X}_{1}\right)$ dan brand awareness $\left(\mathrm{X}_{2}\right)$ terhadap variabel terikat brand loyalty $(\mathrm{Y})$, maka dapat dilihat pada tabel berikut :

Tabel 1.8.

Hasil Uji Regresi Linier Berganda ANOVA ${ }^{a}$

\begin{tabular}{|c|l|l|l|l|l|}
\hline & $\begin{array}{c}\text { Sum } \\
\text { of } \\
\text { Squar } \\
\text { es }\end{array}$ & $\begin{array}{c}\text { D } \\
\text { f }\end{array}$ & $\begin{array}{l}\text { Mean } \\
\text { Squa } \\
\text { re }\end{array}$ & F & Sig. \\
\hline $\begin{array}{l}1 \text { Regressi } \\
\text { on }\end{array}$ & $\begin{array}{l}24.08 \\
5\end{array}$ & 2 & $\begin{array}{l}12.04 \\
3\end{array}$ & $\begin{array}{l}84.82 \\
2\end{array}$ & $\begin{array}{l}.00 \\
0^{\mathrm{b}}\end{array}$ \\
\hline
\end{tabular}

$\left[\begin{array}{l|l|l|l|l|l|}\text { Residual } & 13.77 & 9 & .142 & & \\ \text { Total } & 2 & 7 & & & \\ & 37.85 & 9 & & & \\ 7 & 9 & & & \\ \hline\end{array}\right.$

a. Dependent Variable: Brand Loyality

b. Predictors: (Constant), Brand Awareness, Trust In Brand

Sumber: Hasil analisa

Berdasarkan perhitungan diatas, dapat diketahui bahawa $\mathrm{Ha}$ diterima dan $\mathrm{H}_{\mathrm{o}}$ ditolak. Hal ini dapat dijelaskan melalui besarnya Fhitung 84,822 dengan signifikansi sebesar 0,000 dengan taraf nyata $<\alpha=0,05$. Maka Ha diterima dan $\mathrm{H}_{\mathrm{o}}$ ditolak. Sebaliknya jika Fhitung dengan signifikansi $>\alpha=0,05$ maka $\mathrm{Ha}$ ditolak dan $\mathrm{H}_{\mathrm{o}}$ diterima. Berarti hipotesis yang diajukan yang menyatakan "brand trust $\left(\mathrm{X}_{1}\right)$ dan brand awareness $\left(\mathrm{X}_{2}\right)$ secara simultan berpengaruh positif dan signifikan terhadap brand loyalty (Y) konsumen air mineral merek Aqua di Denpasar" terbukti.

Tabel 1.9.

Hasil Uji Regresi Linier Berganda Coefficients $^{\text {a }}$

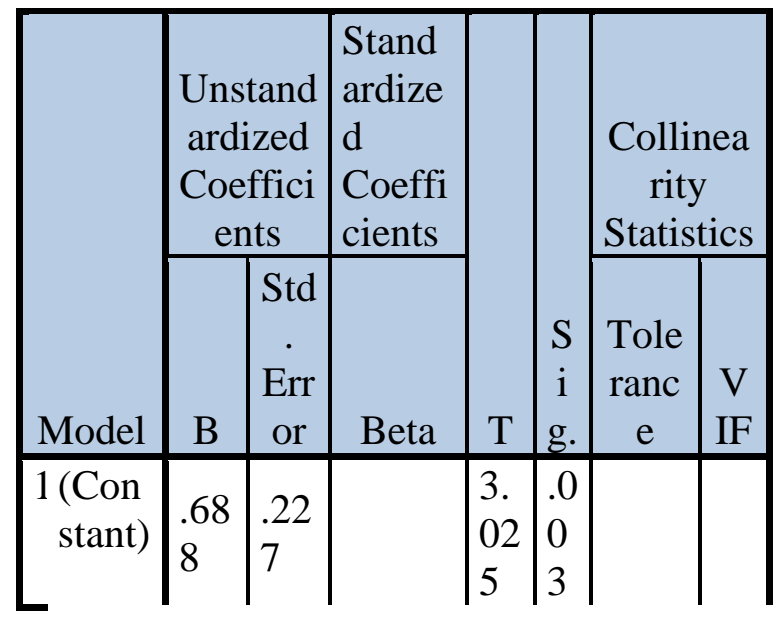


Jurnal Satyagraha, Vol. 01, No. 02, Agustus 2018 - Januari 2019 ISSN : 2620-6358

\begin{tabular}{|l|l|l|l|l|l|l|l|} 
Trust & & & & 3. & .0 & & 3. \\
In & .33 & .11 & .634 & 01 & 0 & .309 & 23 \\
Bran & 7 & 8 & & 0 & 0 & & 6 \\
d & & & & & & & \\
Bran & & & & 6. & .0 & & 3. \\
d & .80 & .11 & .769 & 98 & 0 & .309 & 23 \\
Awar & 1 & 5 & & 0 & 0 & & 6 \\
eness & & & & & \\
\hline
\end{tabular}

a. Dependent Variable: Brand Loyality

\section{Sumber: Hasil analisa}

Berdasarkan data diatas, dapat dijelaskan sebagai berikut :

1. Hasil uji parsial brand trust terhadap variabel brand loyalty diperoleh nilai 0,000 dengan nilai signifikansi $\alpha=5 \%$ $(0,05)$. Sehingga sig $\mathrm{t}<\operatorname{sig} \alpha(0,000<$ $0,05)$ maka $\mathrm{H}_{0}$ ditolak dan Ha diterima. Berarti, ada pengaruh positif dan signifikan antara brand trust terhadap brand loyalty konsumen air mineral merek Aqua di Denpasar. Oleh karena itu, hipotesis yang diajukan bahwa "brand trust berpengaruh positif dan signifikan terhadap brand loyalty konsumen air mineral merek Aqua di Denpasar" terbukti.

2. Hasil uji parsial brand awareness terhadap variabel brand loyalty diperoleh nilai 0,000 dengan nilai signifikansi $\alpha=5 \%(0,05)$. Sehingga sig $\mathrm{t}<\operatorname{sig} \alpha(0,000<0,05)$ maka $\mathrm{H}_{0}$ ditolak dan Ha diterima. Berarti, ada pengaruh positif dan signifikan antara variabel brand awareness terhadap brand loyalty konsumen air mineral merek Aqua di Denpasar. Oleh karena itu, hipotesis yang diajukan bahwa "brand awareness berpengaruh positif dan signifikan terhadap brand loyalty konsumen air mineral merek Aqua di Denpasar" terbukti. Ini berarti bahwa ketika keduaduanya brand trust dan brand awareness sama- sama berjalan dengan baik maka akan sangat berpengaruh terhadap loyalitas

\section{Uji Standardized Coefficient Beta}

Analisis Standardized Coefficient Beta digunakan untuk mengetahui variabel bebas mana yang dominan berpengaruh terhadap variabel terikat. Pengaruh dominan variabel bebas terhadap variabel terikat, diuji dengan menggunakan Standardized Coefficients Beta tertinggi. Adapun hasil uji Standardized Coefficients Beta yang pengujiannya dilakukan dengan program SPSS for Windows versi 20.0, terlihat seperti pada tabel berikut.

Tabel 1.10.

Uji Standardized Coefficients Beta

Coefficients $^{\mathrm{a}}$

\begin{tabular}{|c|c|c|c|c|c|c|c|}
\hline \multirow[b]{2}{*}{ Model } & \multicolumn{2}{|c|}{$\begin{array}{l}\text { Unstand } \\
\text { ardized } \\
\text { Coeffici } \\
\text { ents }\end{array}$} & \multirow[t]{2}{*}{$\begin{array}{c}\text { Stand } \\
\text { ardize } \\
\mathrm{d} \\
\text { Coeffi } \\
\text { cients }\end{array}$} & \multirow[b]{2}{*}{$\mathrm{T}$} & & \multicolumn{2}{|c|}{$\begin{array}{l}\text { Collinea } \\
\text { rity } \\
\text { Statistics }\end{array}$} \\
\hline & B & $\begin{array}{l}\text { Std } \\
\text { Err } \\
\text { or }\end{array}$ & & & $\begin{array}{l}\text { S } \\
\mathrm{i} \\
\mathrm{g} .\end{array}$ & $\begin{array}{c}\text { Tole } \\
\text { ranc } \\
\mathrm{e}\end{array}$ & $\begin{array}{l}\mathrm{V} \\
\mathrm{IF}\end{array}$ \\
\hline $\begin{array}{l}1 \text { (Con } \\
\text { stant) } \\
\text { Trust } \\
\text { In } \\
\text { Bran } \\
\text { d }\end{array}$ & $\begin{array}{l}.68 \\
8\end{array}$ & $\begin{array}{l}.22 \\
7\end{array}$ & .634 & $\begin{array}{l}3 . \\
02 \\
5 \\
3 . \\
01 \\
0\end{array}$ & $\begin{array}{l}.0 \\
0 \\
3\end{array}$ & .309 & $\begin{array}{l}3 . \\
23 \\
6\end{array}$ \\
\hline
\end{tabular}


Jurnal Satyagraha, Vol. 01, No. 02, Agustus 2018 - Januari 2019 ISSN : 2620-6358

$\left[\begin{array}{l|l|l|l|l|l|l|l|}\text { Bran } & & & 6 . & .0 & & 3 . \\ \mathrm{d} & .80 & .11 & .769 & 98 & 0 & .309 & 23 \\ \text { Awar } & 1 & 5 & & 0 & 0 & & 6 \\ \text { eness }\end{array}\right.$

a. Dependent Variable: Brand Loyality

\section{Sumber :hasil analisa}

Dengan melihat hasil Standardized Coefficient Beta dari kedua variabel bebas diatas, yaitu brand trust $\left(\mathrm{X}_{1}\right)$ dan brand awareness $\left(\mathrm{X}_{2}\right)$ maka diketahui bahwa variabel bebas yang berpengaruh dominan terhadap variabel terikat brand loyalty (Y) konsumen air mineral merek Aqua di Denpasar adalah variabel bebas brand awareness $\left(\mathrm{X}_{2}\right)$ dengan Standardized Coefficient Beta yaitu 0,801.

\section{KESIMPULAN DAN SARAN}

Berdasarkan hasil penelitian yang dilandasi dengan kajian teori dan perumusan masalah yang telah dibahas, selanjutnya dapat diambil kesimpulan sebagai berikut:

1. Dari penjelasan tanggapan responden mengenai brand trust pada konsumen air mineral merek aqua di denpasar seperti merek sesuai dengan harapan yang diberikan aqua kepada konsumen seperti cita rasa, konsumen juga percaya terhadap merek, aqua memberikan kepuasan pada pelanggan, aqua dapat diandalkan karena aqua mampu memberikan kepada pelanggan kemasan yang bervariasi jadi bisa di bawa kemana saja dan kapanpun, aqua mampu memberikan asupan mineral yang sesuai untuk mengatasi kekurangan ion dalam tubuh. Secara keseluruhan brand trust dalam kategori baik, airtinya konsumen sudah merasa puas sehingga konsumen memiliki kepercayaan lebih pada merek aqua hal ini dapat dilihat dari nilai thitung $=3,10$ jika dibandingkan dengan nilai ttabel $=1,661$ akan menunjukkan bahwa nilai thitung lebih besar dari nilai ttabel hal ini menyatakan bahwa brand trust berpengaruh positif dan singnifikan terhadap brand loyalty air mineral merek aqua di denpasar. Yang artinya jika brand trust meningkat maka brand loyalty juga akan meningkat

2. tanggapan responden terhadap brand awarenes pada konsumen air mineral merek aqua di denpasar dikatakan dalam kategori baik setelah diuji tingkat kesadaran merek bagaimana konsumen dapat mengenali merek dalam situasi yang berbeda yaitu: timbal balik (feedback) konsumen terhadap merek aqua sehingga membuat aqua berada pada posisi pertama dalam berbagai macam merek, kemampuan konsumen mengingat varian produk seperti yang diberikan aqua melalui logo, desain, simbol dari merek aqua tersebut, aqua memberikan slogan yang mudah diingat sehingga kapan saja dan dimana saja konsumen mendengar, melihat atau membaca dan menonton di televisi konsumen mampu 
Jurnal Satyagraha, Vol. 01, No. 02, Agustus 2018 - Januari 2019 ISSN : 2620-6358

mengenali bahwa slogan ini adalah slogan pada produk aqua. Semuanya ini sangat berpengaruh positif dan signifikan terhadap brand loyalty atau konsumen loyal terhadap merek dengan melakukan pembelian ulang pada merek yang sama ( repeat purchasing) dilihat dari nilai t hitung =6,980 jika dibandingkan dengan nilai ttabel $=1,661$, akan menunjukkan bahwa nilai $\mathrm{t}$ hitung lebih besar dari nilai ttabel itu artinya jika brand awareness meningkat maka brand loyalty juga akan meningkat

3. Brand trust dan brand awareness sama - sama berpengaruh terhadap brand loyalty dilihat dari tingkat pembelian kembali dengan konsumen setia kepada aqua, hanya dalam keadaan terpaksa konsumen mempertimbangkan untuk membeli merek air mineral yang berbeda, konsumen mencari toko lain apabila di toko tersebut tidak tersedia produk aqua, dan setelah konsumen merasa bahwa kebutuhannya di penuhi oleh merek aqua tersebut maka dengan sendirinya konsumen akan merekomendasikan merek aqua kepada orang lain. secara simultan Loyalitas pelanggan juga akan tergantung pada tingkat kepercayaan pelanggan pada merek dan juga kesadaran merek. Ketika seorang pelanggan percaya pada suatu merek dalam hal ini merek aqua maka pelanggan tersebut akan lebih menunjukkan sikap dan prilaku positif kepada merek aqua karena aqua mampu memberikan hasil yang positif. brand awareness juga merupakan kunci pembuka untuk masuk ke elemen lainya, kemampuan dari konsumen potensial untuk mengenali atau mengingat bahwa merek aqua termasuk dalam kategori produk tertentu menunjukkan apabila kesadaran merek aqua meningkat maka juga akan meningkatnya loyalitas terhadap merek aqua secara simultan juga dapat dibuktikan dengan nilai Fhitung $=84,822$ jika dibandingkan dengan nilai Ftabel = 3,090, maka nilai Fhitung lebih besar dari nilai Ftabel. Dilihat dari nilai $R$ square sebesar 0,63 menunjukkan bahwa brand trust dan brand awareness mempengaruhi brand loyalty sebesar $63,60 \%$ sedangkan sisanya $=100-63,60 \%=36,40 \%$ di pengaruhi oleh faktor lain yang tidak diteliti oleh peneliti

4. Variabel bebas yang dominan berpengaruh terhadap brand loyalty adalah brand awareness dengan nilai standardized coefficient Beta sebesar 0,801

\section{SARAN}

1. Kepada Perusahaan

Bagi perusahaan mengingat bahwa dalam penelitian ini brand trust dan 
Jurnal Satyagraha, Vol. 01, No. 02, Agustus 2018 - Januari 2019 ISSN : 2620-6358

brand awareness berpengaruh positif dan signifikan terhadap brand loyalty, dan variabel bebas yang paling dominan berpengaruh terhadap brand loyalty konsumen Aqua adalah brand awareness (kesadaran merek). Jadi bagi pihak perusahaan untuk kedepannya lebih memperhatikan dan mempertahankan tingkat kesadaran merek aqua dipikiran konsumen dengan memperkuat merek, logo, desain yang simpel, praktis dan lebih modern sehingga lebih bervariasi dan juga iklan yang menarik. hal ini untuk menciptakan kemampuan untuk menjaga pelanggan yang saat ini dan membuat mereka loyal kepada merek aqua dalam jangka panjang.

\section{Peneliti Selanjutnya}

Di harapkan agar menambah jumlah sampel dan dapat menambah variabel bebas lain sehingga diharapkan dapat memberikan hasil penelitian yang lebih baik lengkap dan akurat serta bermanfaat.

\section{DAFTAR PUSTAKA}

Bison, Simamora. (2004). Pandua Riset Perilaku Konsumen. PT. Gramedia Pustaka Utama. Jakarta

Delgado- Ballester,E and Manuera- Aleman, J. L. (2005)" Does Brand Trust
Matter to Brand Equity? Jurnal of Product and Brand Management.

Istijanto, (2005). Aplikasi Praktis Riset Pemasaran Plus 36 Topik Riset Pemasaran Siap Terap. PT. Gramedia Pustaka Utama, Jakarta

Prasetya Diar Skriptian Eko, 2016 “ pengaruh Brand Image, Brand Awereness dan Brand Trust Terhadap Brand Loyalty Konsumen Air Mineral Merek Aqua Pada Mahasiswa Universitas Muhammadiyah Surakarta.

Kotler dan Keller, 2009. Manajemen Pemasaran. Jilid 1. Edisi ke 13 Jakarta: Erlangg.

Rangkuti, Freddy. 2002. The Power of Brand. Jakarta: PT. Gramedia Pustaka Utama

Wahyono teguh. 2005.Sistem Informasi: Konsep Dasar, Amalisis Desaim dan Implementasi. Jakarta : Graha Ilmu 